\title{
PENGARUH KECEPATAN PUTAR PENGGERAK MULA MIKROHIDRO TERHADAP KELUARAN GENERATOR INDUKSI 1 FASE 4 KUTUB
}

\author{
Agus Supardi, Ardhiya Faris Rachmawan \\ Jurusan Teknik Elektro Fakultas Teknik Universitas Muhammadiyah Surakarta \\ Jl. A. Yani Tromol Pos 1 Pabelan Kartasura 57102 Telp 0271717417 \\ Email: Agus.Supardi@ums.ac.id
}

\begin{abstract}
ABSTRAKSI
Daerah-daerah terpencil di Indonesia masih banyak yang belum tersentuh oleh program elektrifikasi akibat tidak terjangkaunya daerah tersebut oleh infrastruktur kelistrikan yang ada. Di sisi lain, seringkali daerah-daerah terpencil tersebut memiliki potensi tenaga air yang dapat dimanfaatkan untuk membangkitkan listrik. Dalam realitanya debit air yang tersedia seringkali berubah - ubah akibat pengaruh musim. Perubahan debit air ini akan mempengaruhi kecepatan putar turbin airnya. Generator induksi dapat dijadikan sebagai salah satu alternatif untuk pembangkit listrik skala kecil. Apabila generator induksi diaplikasikan pada sistem pembangkit mikrohidro maka kecepatan putarnya akan ditentukan oleh turbin airnya. Oleh karena itu perlu dilakukan penelitian untuk mengetahui pengaruh kecepatan putar penggerak mula terhadap tegangan dan frekuensi generator induksi.

Penelitian diawali dengan pengkopelan generator induksi 1 fase dan penggerak mulanya. Dalam penelitian ini, penggerak mula ditirukan di laboratorium dengan menggunakan motor listrik. Kecepatan putar generator induksi diatur dengan jalan mengatur kecepatan putar penggerak mulanya. Setelah generator induksi berputar dengan kecepatan tertentu, selanjutnya dilakukan pengukuran tegangan dan frekuensi dengan menggunakan power quality analyzer. Pengujian dilanjutkan dengan menghubungkan beban listrik sebesar 40 dan 80 watt pada terminal generator induksi. Beban yang dihubungkan terdiri dari beban resistif, beban induktif, dan beban resistif induktif. Beban resistif yang dipakai berupa lampu pijar sedangkan beban induktifnya berupa lampu TL.

Hasil penelitian menunjukkan bahwa kecepatan putar penggerak mula mikrohidro akan mempengaruhi tegangan dan frekuensi generator induksi 1 fase 4 kutub. Semakin tinggi kecepatan putarnya maka semakin tinggi pula tegangan dan frekuensinya. Hasil penelitian menunjukkan bahwa generator induksi 1 fase yang diputar antara 1300 sampai 1600 rpm akan menghasilkan tegangan sebesar 118,7 sampai 245,9 Volt dan frekuensi sebesar 39,9 sampai $51,6 \mathrm{~Hz}$ ketika dihubungkan dengan beban sebesar 40 dan 80 watt.
\end{abstract}

Kata kunci: kecepatan putar, generator induksi 1 fase, tegangan dan frekuensi.

\section{PENDAHULUAN}

Daerah-daerah terpencil di Indonesia masih banyak yang belum tersentuh oleh program elektrifikasi akibat tidak terjangkaunya daerah tersebut oleh infrastruktur kelistrikan yang ada. Di sisi lain, seringkali daerah-daerah terpencil tersebut menyimpan potensi tenaga air dengan tinggi jatuh air (head) rendah yang dapat dimanfaatkan untuk membangkitkan listrik. Di daerah seperti itu lebih cocok dibangun pembangkit listrik berkapasitas kecil tetapi jumlah unitnya banyak, menyesuaikan dengan persebaran rumah penduduk.

Untuk aplikasi sistem pembangkit listrik tenaga air, biasanya digunakan suatu turbin air untuk memutar generator. Suatu turbin air didesain dengan kecepatan putar tertentu. Mafrudin dan Dwi Irawan (2012) melaporkan bahwa turbin air tipe cross-flow yang diuji menghasilkan kecepatan putar sebesar $68 \mathrm{rpm}$ pada saat generatornya tidak dihubungkan dengan beban. Simarmata (2015) memaparkan bahwa unjuk kerja kincir air tipe sudu lengkung undershot yang diputar dengan kecepatan putar $50 \mathrm{rpm}$ akan dipengaruhi oleh jumlah sudunya. Efisiensi tertinggi diperoleh pada variasi 5 sudu. Sule dan Timbayo (2012) melaporkan bahwa torsi, daya dan efisiensi maksimum dari roda air arus bawah untuk sudu plat datar diperoleh untuk sudu plat datar dengan 8 sudu dan kecepatan putar 19 rpm.

Generator induksi bisa dijadikan salah satu alternatif pilihan untuk aplikasi sistem pembangkit skala kecil. Bansal (2005) memaparkan bahwa motor induksi 3 fase dapat dioperasikan sebagai generator induksi jika rotornya diputar pada kecepatan tertentu. Fukami et al (1999) melaporkan bahwa generator induksi 1 fase dapat dihasilkan dari 
mesin induksi 3 fase yang dioperasikan sebagai generator. Ouhroche (1995) memaparkan manfaat yang diperoleh dari pemanfaatan generator induksi antara lain konstruksinya kuat dan sederhana, memerlukan sedikit perawatan, mudah dalam pengoperasiannya, harga unitnya murah, dan mempunyai keandalan yang tinggi.

Pemanfaatan generator induksi sebagai pembangkit listrik stand-alone juga menimbulkan permasalahan. Apabila generator induksi diterapkan pada suatu sistem pembangkit listrik di daerah terpencil maka akan dihadapkan pada kenyataan bahwa potensi tenaga penggerak mula yang digunakan untuk memutar generator induksi tersebut adalah tidak konstan. Debit air pada sistem pembangkit listrik mikrohidro seringkali berubah-ubah akibat pengaruh musim. Biasanya beban listrik yang harus disuplai oleh sistem pembangkit tersebut juga tidak konstan. Kondisi ini akan berdampak besar terhadap tegangan dan frekuensi pembangkit tersebut. Oleh karena itu, perlu dilakukan suatu penelitian untuk mengetahui karakteristik tegangan dan frekuensi generator induksi 1 fase yang akan diterapkan pada daerah - daerah tersebut.

\section{METODE PENELITIAN}

2.1 Bahan dan Peralatan yang digunakan Bahan dan peralatan yang digunakan dalam penelitian ini adalah :

a. Generator induksi 1 fase yang digunakan untuk membangkitkan listrik

b. Motor listrik yang digunakan sebagai penggerak mula generator induksi.

c. Streng $(v$ belt $)$ yang digunakan untuk mengkopel generator induksi dengan penggerak mulanya.

d. Pully dengan rasio 1: 1 yang digunakan sebagai tempat sabuk transmisi.

e. Dudukan besi yang digunakan sebagai tempat untuk memasang generator induksi dan penggerak mulanya.

f. Mur baut yang digunakan untuk memasang peralatan pada dudukan besi.

g. Tachometer yang digunakan untuk mengukur kecepatan putar generator induksi. h. Power quality analyzer yang digunakan untuk mengukur tegangan dan frekuensi generator induksi.

\subsection{Langkah-langkah Pengujian}

Langkah-langkah yang dilakukan untuk mengamati karakteristik generator induksi adalah sebagai berikut :

a. Generator induksi dikopel dengan penggerak mulanya.

b. Kapasitor eksitasi dan peralatan ukur dihubungkan pada terminal generator induksi.

c. Generator induksi diputar hingga mencapai suatu kecepatan tertentu dengan cara mengatur kecepatan putar penggerak mulanya.

d. Pengukuran tegangan, kecepatan putar dan frekuensi keluaran generator induksi dilakukan pada saat tanpa beban, berbeban resistif, berbeban induktif dan berbeban resistif induktif.

\subsection{Diagram Alir Penelitian}

Diagram alir penelitian ditunjukkan pada gambar 1.

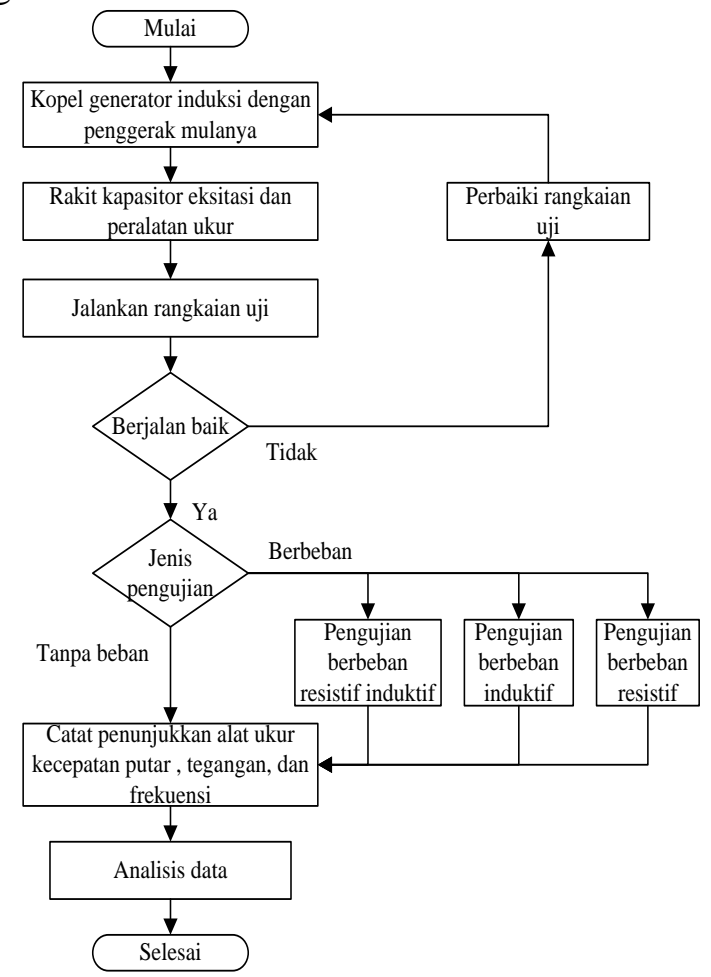

Gambar 1 Diagram Alir Penelitian 


\section{HASIL DAN PEMBAHASAN}

\subsection{Hasil Pengujian Generator Tanpa Beban}

Hasil pengujian generator induksi pada saat tanpa beban ditunjukkan pada gambar 2 dan gambar 3. Ukuran kapasitor eksitasi yang dihubungkan adalah sebesar 16 mikrofarad.

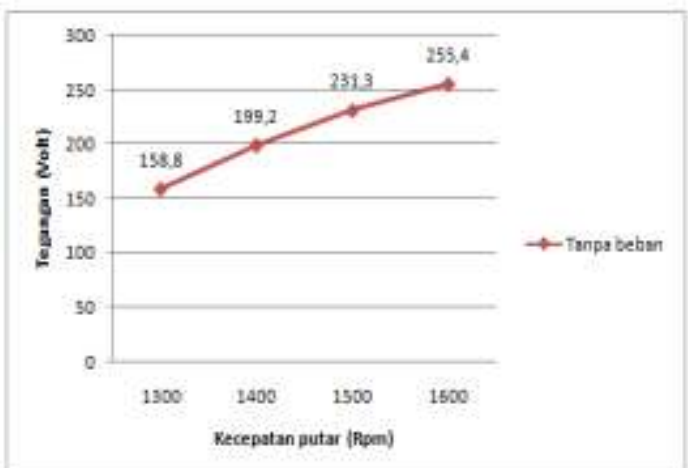

Gambar 2 Hubungan kecepatan putar dengan tegangan pada generator induksi tanpa beban.

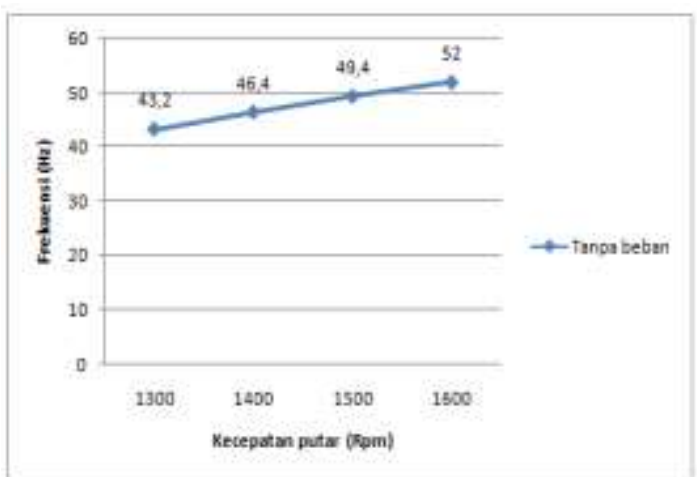

Gambar 3 Hubungan kecepatan putar dengan frekuensi pada generator induksi tanpa beban.

Pada saat mesin induksi difungsikan sebagai generator maka rotornya harus diputar oleh suatu penggerak mula. Bila suatu konduktor diputar di dalam medan magnet (kumparan stator) maka akan dibangkitkan tegangan sebesar $\mathrm{e}=$ B.l.v dengan e adalah tegangan induksi yang dihasilkan, B adalah fluks magnetik, 1 adalah panjang konduktor yang dilewati medan magnet, dan $\mathrm{v}$ adalah kecepatan medan magnet melewati konduktor.

Pada belitan stator generator induksi harus selalu terdapat fluks magnetik walaupun nilainya kecil (fluks sisa). Adanya fluks sisa ini akan diperlukan untuk membangkitkan tegangan induksi pada saat rotornya diputar. Tegangan induksi ini terinduksi pula pada sisi stator dan akan menimbulkan arus yang akan mengisi muatan pada kapasitor sampai terjadi keseimbangan.

Gambar 2 menunjukkan bahwa tegangan keluaran generator induksi pada saat tanpa beban akan dipengaruhi oleh kecepatan putar penggerak mula generatornya. Semakin tinggi kecepatan putar penggerak mula generator induksi maka tegangan yang dihasilkannya juga semakin tinggi. Pada pengujian ini, ukuran kapasitor yang dihubungkan pada terminal generator induksi dibuat tetap yaitu sebesar 16 mikrofarad sehingga arus eksitasinya juga akan tetap. Dengan arus eksitasi yang tetap maka medan magnet yang dihasilkannya juga tetap. Dengan demikian sesuai teori maka tegangan keluaran generator induksi hanya dipengaruhi oleh kecepatan putar generator induksi. Generator induksi yang digunakan dalam percobaan adalah mesin induksi 1 fase 220 volt 4 kutub, sehingga kecepatan sinkron dari medan magnet stator adalah sebesar $1500 \mathrm{rpm}$ bila frekuensinya sebesar $50 \mathrm{~Hz}$. Dengan demikian bila mesin difungsikan sebagai generator induksi maka rotornya seharusnya diputar pada kecepatan sekitar 1500 rpm agar dapat membangkitkan tegangan 220 volt dan frekuensi $50 \mathrm{~Hz}$. Bila kecepatannya lebih kecil dari $1500 \mathrm{rpm}$, maka tegangan yang dibangkitkan juga lebih kecil dari 220 volt, begitu juga sebaliknya.

Gambar 3 menujukkan bahwa pada saat tanpa beban, semakin tinggi kecepatan putar penggerak mula generator induksi maka frekuensi yang dihasilkannya akan semakin tinggi. Hal ini sesuai teori bahwa frekuensi generator induksi akan ditentukan oleh kecepatan putar rotor dari generator induksi. Generator yang dipakai mempunyai jumlah kutub yang tetap yaitu sebesar 4 kutub. Oleh karena itu, frekuensi hanya ditentukan oleh kecepatan putar mengikuti rumus $f=n_{s} \times p$ /120. Dengan adanya slip dalam mesin induksi maka kecepatan putar rotor tidak akan sama dengan kecepatan putar medan stator. Dengan demikian frekuensi yang dihasilkan oleh generator pada saat diputar $1500 \mathrm{rpm}$ sedikit lebih kecil dari $50 \mathrm{~Hz}$. Hasil pengujian menunjukkan dengan kecepatan putar $1500 \mathrm{~Hz}$ akan dihasilkan frekuensi 49,4 Hz. 


\subsection{Hasil Pengujian Generator Dengan Beban Resistif}

Hasil pengujian generator induksi pada saat dibebani dengan beban resistif sebesar 40 dan 80 watt ditunjukkan pada gambar 4 dan gambar 5 .

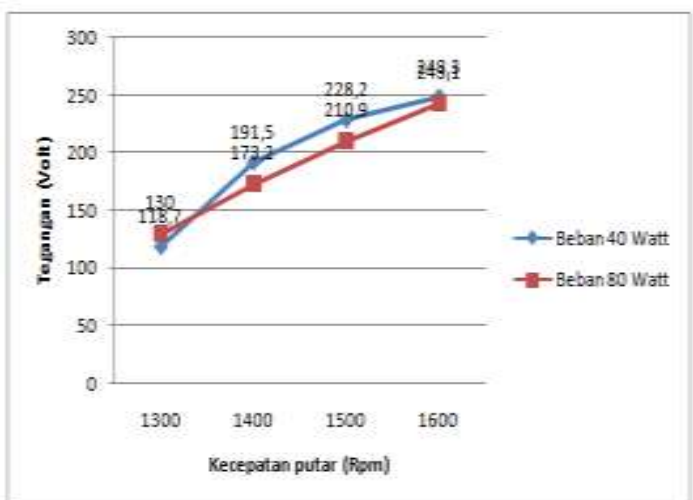

Gambar 4 Hubungan kecepatan putar terhadap tegangan generator induksi dengan beban resistif

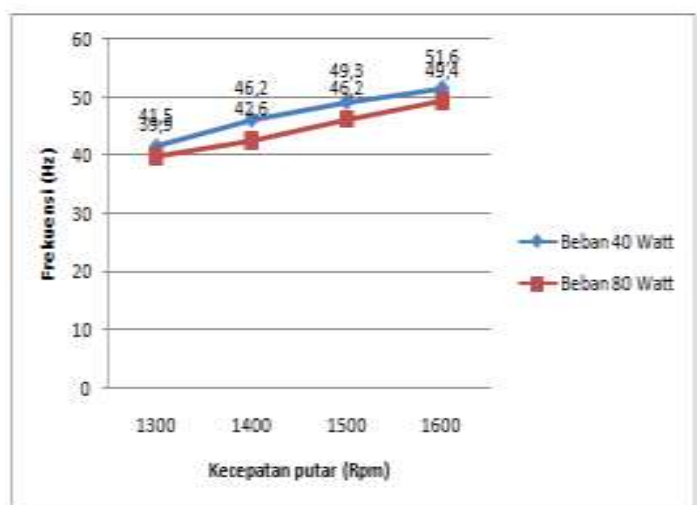

Gambar 5 Hubungan kecepatan putar terhadap frekuensi generator induksi dengan beban resistif

Pada saat generator induksi dihubungkan dengan beban, maka akan arus akan dialirkan menuju ke beban. Arus ini akan berinteraksi dengan medan magnet pada kumparan stator sebagai reaksi atas gaya mekanik yang diberikan pada rotornya. Pada saat motor induksi diubah menjadi generator induksi maka dibutuhkan daya reaktif atau daya magnetisasi untuk membangkitkan tegangan pada terminal keluarannya. Kapasitor dihubungkan pada terminal stator sebagai penyedia daya reaktif yang besarnya disesuaikan dengan daya reaktif yang diperlukan.
Gambar 4 menunjukkan bahwa pada saat generator induksi dibebani dengan beban resistif maka kecepatan putar akan mempengaruhi tegangan keluarannya. Semakin tinggi kecepatan putar penggerak mula generator induksinya maka tegangannya akan semakin tinggi. Untuk kecepatan putar yang sama, jika dibandingkan dengan tegangan pada saat tanpa beban maka penambahan beban resistif sebesar $40 \mathrm{~W}$ akan menurunkan tegangan generatornya. Ketika beban generator dinaikkan lagi menjadi $80 \mathrm{~W}$ maka tegangan generatornya akan semakin turun. Hal ini sesuai teori bahwa semakin besar daya beban yang dihubungkan pada generator maka arus beban yang harus disuplai oleh generator menjadi semakin tinggi. Semakin tinggi arus maka semakin tinggi pula susut tegangan pada belitan stator. Hasil pengujian juga menunjukkan bahwa untuk daya beban yang sama maka semakin tinggi kecepatan putar penggerak mulanya maka penurunan tegangan pada pembebanan resistif menjadi lebih kecil.

Gambar 5 menunjukkan bahwa pada saat generator induksi dibebani dengan beban resistif maka kecepatan putar juga akan mempengaruhi frekuensinya. Semakin tinggi kecepatan putar penggerak mula generator induksi maka semakin tinggi frekuensinya. Untuk kecepatan putar yang sama, jika dibandingkan dengan frekuensi pada saat tanpa beban maka penambahan beban resistif sebesar $40 \mathrm{~W}$ akan menurunkan frekuensi generator. Ketika beban dinaikkan lagi menjadi $80 \mathrm{~W}$ maka frekuensi generatornya menjadi semakin turun lagi. Semakin besar beban yang dihubungkan maka semakin besar torsi yang dibutuhkan untuk memutar generatornya. Dalam percobaan ini, tidak dilakukan pengontrolan pada penggerak mula dari generatornya sehingga daya mekanisnya tetap konstan. Ketika daya elektrisnya dinaikkan maka beban penggerak mula ikut naik dan dampaknya adalah putaran generatornya akan melambat. Hasil pengujian juga menunjukkan bahwa untuk daya beban yang sama maka semakin tinggi kecepatan putar penggerak mulanya maka semakin kecil penurunan frekuensinya. 


\subsection{Hasil Pengujian Generator Dengan Beban Induktif}

Hasil pengujian generator induksi pada saat dibebani dengan beban induktif sebesar 40 dan 80 watt ditunjukkan pada gambar 6 dan gambar 7 .

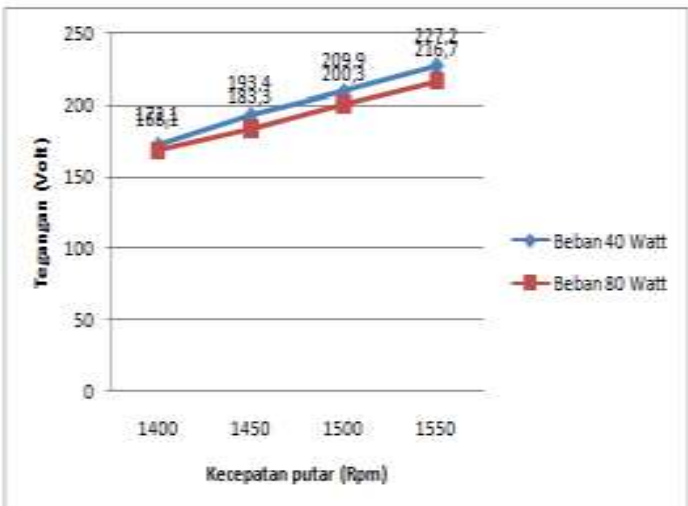

Gambar 6 Hubungan kecepatan putar terhadap tegangan generator induksi dengan beban induktif

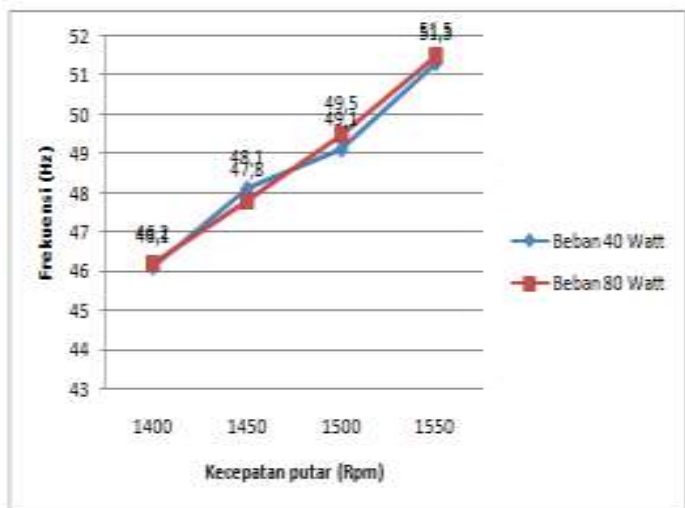

Gambar 7 Hubungan kecepatan putar terhadap frekuensi generator induksi dengan beban induktif.

Generator induksi yang dioperasikan stand alone membutuhkan suatu bank kapasitor untuk menyuplai daya reaktif. Daya reaktif yang diberikan harus sama atau lebih besar dari daya reaktif yang diambil mesin ketika beroperasi sebagai motor. Tegangan terminal generator akan bertambah dengan penambahan kapasitansi kapasitor.

Ketiadaan kumparan medan magnet dalam generator induksi mengakibatkan generator induksi tidak bisa menghasilkan daya reaktif sendiri. Sebaliknya, generator induksi justru membutuhkan suplai daya reaktif. Pada saat generator induksi dihubungkan dengan beban induktif maka generator juga harus menyuplai kebutuhan daya reaktif yang diperlukan oleh beban. Dengan demikian jika ukuran kapasitor yang dihubungkan dibuat tetap maka hanya sebagian daya reaktif kapasitor yang dialirkan ke generator sehingga tegangan keluarannya juga turun. Kondisi penurunan tegangan ini ditunjukkan pada gambar 6 .

Hasil pengujian juga menunjukkan bahwa dengan ukuran kapasitor dan daya beban yang tetap maka beban induktif membutuhkan kecepatan putar yang lebih tinggi dibanding dengan beban resistif untuk membangkitkan tegangan yang sama. Hal ini disebabkan fluks magnet belitan stator akan turun pada saat beban induktif dihubungkan pada generator sehingga tegangan yang dibangkitkan generator juga akan turun. Oleh karena itu sesuai dengan teori untuk menaikkan tegangan generatornya maka kecepatan putar generatornya harus dinaikkan juga. Beban induktif yang digunakan dalam pengujian ini berupa lampu TL sehingga memerlukan tegangan tertentu agar dapat menyala. Dalam pengujian ini untuk menyalakan lampu TL sebesar $40 \mathrm{~W}$ maka generator harus diputar minimal $1400 \mathrm{rpm}$. Kecepatan putar ini lebih tinggi dari kecepatan putar yang diperlukan oleh beban resistif untuk daya yang sama.

Gambar 7 menunjukkan bahwa semakin tinggi kecepatan putar penggerak mula generator induksi maka semakin tinggi frekuensinya. Bila dibandingkan dengan beban resistif maka frekuensinya tidak banyak berubah. Untuk kecepatan putar yang sama maka frekuensinya juga relatif sama. Hal ini disebabkan dalam pengujian ini generatornya mempunyai jumlah kutub yang sama, sehingga frekuensinya hanya ditentukan oleh kecepatan putar penggerak mula generatornya.

\subsection{Hasil Pengujian Generator Dengan Beban Resistif Induktif}

Hasil pengujian generator induksi pada saat dibebani dengan beban resistif induktif ditunjukkan pada gambar 8 dan gambar 9 . Beban yang digunakan adalah 40 Watt resistif dikombinasi 40 watt induktif dan 80 watt resistif dikombinasi 80 watt induktif. 


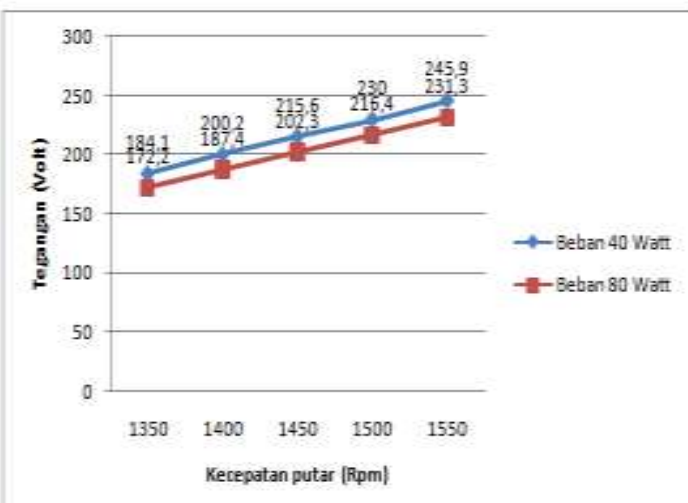

Gambar 8 Hubungan kecepatan putar terhadap tegangan generator induksi dengan beban resistif dan induktif

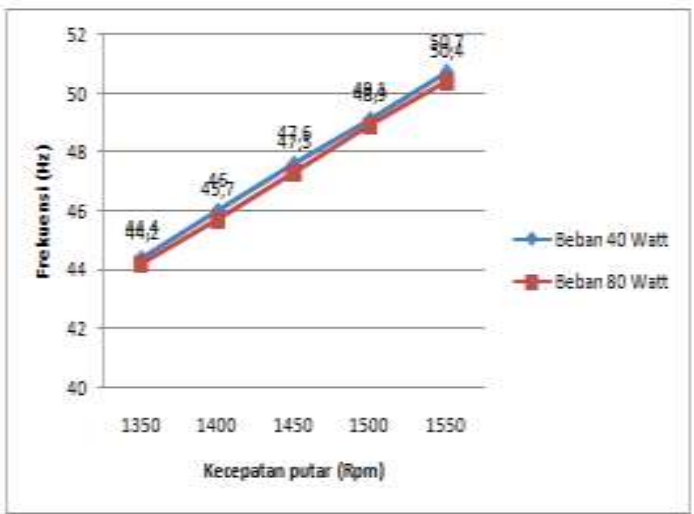

Gambar 9 Hubungan kecepatan putar terhadap frekuensi generator induksi dengan beban resistif dan induktif.

Gambar 8 menunjukkan kecenderungan yang sama dengan pembebanan resistif dan pembebanan induktif dimana semakin tinggi kecepatan putar penggerak mulanya maka semakin tinggi tegangan generatornya. Data juga menunjukkan untuk kecepatan putar yang sama maka tegangan generator induksi yang dibebani dengan beban resistif induktif lebih tinggi dari tegangan generator induksi yang dibebani dengan beban induktif saja.

Gambar 9 juga menunjukkan kecenderungan yang sama dengan pembebanan resistif dan pembebanan induktif dimana semakin tinggi kecepatan putarnya maka semakin tinggi frekuensinya. Untuk kecepatan putar yang sama maka frekuensi generator induksi yang dibebani dengan beban resistif induktif lebih rendah dari frekuensi generator induksi yang dibebani dengan beban induktif saja. Hal ini disebabkan pada kecepatan putar tersebut daya beban resistif induktif yang dihubungkan pada generator induksi lebih besar dari daya beban induktif saja. Sesuai teori maka semakin besar daya yang dihubungkan maka semakin kecil tegangan generatornya.

\section{KESIMPULAN}

Berdasarkan hasil penelitian dan pembahasan dapat ditarik kesimpulan sebagai berikut :

1. Semakin tinggi kecepatan putar penggerak mula generator induksi maka semakin tinggi pula tegangan dan frekuensinya.

2. Generator induksi yang diputar antara 1300 sampai dengan $1600 \mathrm{rpm}$ menghasilkan tegangan sebesar 118,7 sampai 248,3 Volt dan frekuensi sebesar 39,9 sampai $51,6 \mathrm{~Hz}$ ketika dihubungkan dengan beban resistif sebesar 40 dan 80 watt.

3. Generator induksi yang diputar antara 1400 sampai dengan $1550 \mathrm{rpm}$ menghasilkan tegangan sebesar 172,1 sampai 227,2 Volt dan frekuensi sebesar 46,1 sampai $51,5 \mathrm{~Hz}$ ketika dihubungkan dengan beban induktif sebesar 40 dan 80 watt.

4. Generator induksi yang diputar antara 1350 sampai dengan $1550 \mathrm{rpm}$ menghasilkan tegangan sebesar 172,2 sampai 245,9 Volt dan frekuensi sebesar 44,2 sampai $50,7 \mathrm{~Hz}$ ketika dihubungkan dengan beban resistif induktif sebesar 40 dan 80 watt.

\section{UCAPAN TERIMA KASIH}

Ucapan terima kasih disampaikan kepada DIKTI selaku pemberi dana hibah penelitian hibah bersaing sehingga penelitian ini dapat dilaksanakan. Ucapan terima kasih juga disampaikan kepada LPPM UMS yang telah memfasilitasi penyelenggaraan berbagai kegiatan terkait hibah penelitian ini.

\section{DAFTAR PUSTAKA}

Bansal, R.C., 2005, Three-Phase Self-Excited Induction Generators: An Overview, IEEE Transactions On Energy Conversion

Fukami T, Kaburaki Y, Kawahara S, Miyamoto T., 1999, Performance 
Analysis of a Self-Regulated SelfExcited Single Phase Induction Generator Using a Three-Phase Machine". IEEE Trans Energy Conver 1999;14(3):622-7.

Mafrudin, Irawan D., 2012, Pembuatan Turbin Mikrohidro Tipe Cross-Flow Sebagai Pembangkit Listrik Di Desa Bumi Nabung Timur, Jurnal Turbo, Vol. 3 N0. 2, 2012, Teknik Mesin Universitas Muhammadiyah Metro

Ouhrouche M.A. and Chaine Q.M., 1995, EMTP Based Study of Self Excitation Phenomenon in an Induction Generator
Simarmata, M.Y., 2015, Pengaruh Jumlah Sudu Terhadap Unjuk Kerja Kincir Air Tipe Sudu Lengkung Undershot, Jurnal Mahasiswa Mesin, Volume V No 041.29.I.79 2015, Fakultas Teknik Universitas Brawijaya

Sule,L., Timbayo, E.S., 2012, Analisa Performance Roda Air Arus Bawah Untuk Sudu Plat Datar Dengan Variasi Jumlah Sudu Laju, Prosiding Hasil Penelitian Fakultas Teknik, Volume 6 Desember 2012 